Tezel, A., Koskela, L., Tzortzopoulos, P., Talebi, S., and Miron, L. (2018). "Continuous Improvement Cells in the Highways Sector" In: Proc. $26^{\text {th }}$ Annual Conference of the International. Group for Lean Construction (IGLC), González, V.A. (ed.), Chennai, India, pp. 691-701. DOI: doi.org/10.24928/2018/0406. Available at: www.iglc.net.

\title{
CONTINUOUS IMPROVEMENT CELLS IN THE HIGHWAYS SECTOR
}

\author{
Algan Tezel ${ }^{1}$, Lauri Koskela ${ }^{2}$, Patricia Tzortzopoulos ${ }^{3}$, \\ Saeed Talebi ${ }^{4}$, and Luciana Miron ${ }^{5}$
}

\begin{abstract}
In line with its performance improvement and Lean Construction agenda, the highways supply chain in the UK has commenced many Continuous Improvement (CI) cells in recent years. The CI cell is a small-group work coordination and improvement technique that is frequently used in many industries as part of their lean transformations. The technique has also its links to some key lean concepts and practices like continuous improvement (kaizen), Visual Management and hoshinkanri policy deployment.

This paper presents a summary of a detailed research aiming to understand the execution of the CI cells in the highways supply chain in the UK with their associated benefits and challenges through a study of $12 \mathrm{CI}$ cells at the main client organisation. Alongside a set of benefits and challenges, the current CI cell execution mechanism and some suggestions to improve the current practice were also presented in the paper.
\end{abstract}

\section{KEYWORDS}

Continuous improvement, Lean construction, Visual Management, HoshinKanri, highways.

\section{INTRODUCTION}

With ambitious performance targets mandated by the government and the main public client, the highways sector in the UK has been under pressure to improve its operations. As one of the resorts for this improvement, the sector has been actively engaged in Lean Construction (LC) since the late 2000s. Alongside the Last Planner System and Visual Management, utilising Continuous Improvement (CI) cells has been a subject of interest for the sector since then. Following the first CI cells in the supply chain, which were started at some construction service providers around 2009, the main client also initiated

Lecturer, School of Art, Design and Architecture, Huddersfield University, UK, a.tezel@ hud.ac.uk

Professor, School of Art, Design and Architecture, Huddersfield University, UK, 1.koskela @ hud.ac.uk

Professor, School of Art, Design and Architecture, Huddersfield University, UK,

p.tzortzopoulos@hud.ac.uk

4 Lecturer, School of Art, Design and Architecture, Huddersfield University, UK, s.talebi@ hud.ac.uk

5 Associate Professor, School of Architecture, Federal University of Rio Grande do Sul, Brazil, luciana.miron@ufrgs.br 
CI cells among its internal teams in 2014. The CI cell is essentially a small-group work improvement mechanism that is used to put the kaizen (continuous improvement) principle in effect through employee participation (Wilkinson et al 1997).

Building on Miron's et al (2016) exploration of the evaluation of CI cells, this paper presents a summary of the initial findings of a research project aiming to understand the benefits of and improvement opportunities for CI cells in the highways supply chain in the UK.

\section{LITERATURE REVIEW}

\section{CONTINUOUS IMPROVEMENT CELLS}

The CI cell is a small-group task coordination and work improvement technique developed from Quality Circles (QCs), a form of employee involvement mainly used for gradual quality improvement. In the execution of CI cells, a group of three to twelve employees regularly meet under the leadership of their supervisor in order to systematically identify work related problems, analyse solutions, and to solve those problems (Dale et al. 2001; Miron et al. 2016; Barad 2018). The intrinsic CI cell aim of problem solving and gradual work improvement through group effort links the concept to the continues improvement or kaizen principle of lean thinking (Brunet and New 2003; Imai 2012; Maaruf and Mahmoud 2016). Alongside quality management (Love and Li 2000), with their regular performance review and improvement motives, CI cells are also classified as part of performance management (Bell 2005; Brown 2013).

As a CI cell regularly exposes the team to the information associated with their work in the form of team performance metrics, team-member availability, work-related issues, the continuous improvement process or work coordination/follow-up, CI cellscan also be included in efforts toward increasing process transparency within Visual Management, an information management strategy that relies on the effectiveness of sensory communication (Suzaki 1993; Bititci et al. 2016). The information presented on CI cell boards of different teams remains accessible to all and by creating information fields, the boards serve as a summary of the team performance and the issues for the interested (Galsworth 2005; Tezel et al. 2016).

Additionally, the importance of having structured team coordination meetings and two-way communication channels from the operational level to the strategic management level and vice versa has been underlined in disseminating organisational strategic goals as part of hoshinkanri, a strategic management framework originally conceived in Japan and recognised for developing a deployment process that integrates business strategy and operations execution (Akao 1991; Witcher and Butterworth 2001; da Silveria et al. 2017). CI cells can therefore be perceived as tools to establish that link between the strategic and operational level, in which short-term team targets toward strategic goals are regularly communicated and controlled, and any problems in achieving those targets are resolved in a systematic manner. Figure 1 illustrates this positioning of CI cells at the intersection of the hoshinkanri, Visual Management and kaizen concepts, recognising CI cells' functional role within each concept. This kind of positioning of CI cells with its roles exposed in different lean related efforts could not be identified form the literature. 


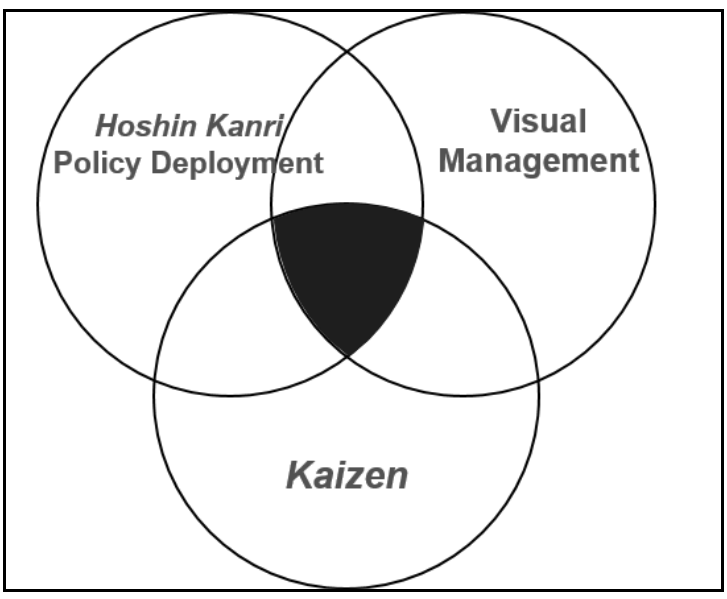

Figure 1: CI cells is a group management technique that can be positioned at the intersection of the hoshinkanri, Visual Management and kaizen efforts at an organisation.

\section{BENEFITS OF CONTINUOUS IMPROVEMENT CELLS}

Most of the discussions on CI cell benefits and challenges are from the QC literature. The following benefits can be achieved by deploying CI cells (Miron et al 2016); (i) job enrichment through involving employees into the decision making process and providing them with greater autonomy (Osayawe and McAndrew 2005; Barad 2018), (ii) cost savings through developing the problem solving skills of employees and capturing work improvement ideas (Pereira and Osburn 2007), (iii) setting a systematic goal-setting and feedback mechanism for employees, which will raise the level of understanding of the work conditions and requirements (Osayawe and McAndrew 2005), (iv) increased participation and team work for employees, which will increase the employee motivation and involve employees in the decision making process (Prado2001), and (v) increased interaction within the members of a CI cell and between the members of different CI cells (Pereira and Osburn 2007).

\section{CHALLENGES FOR CONTINUOUS IMPROVEMENT CELLS}

There is an established literature as to the challenges for small-group activities in continuous improvement. Those discussions mostly focus on QCs as the basis of CI cells. QCs were found of limited value in changing employee behaviour and organisational culture (Bradley and Hill 1983). Organisations often experience difficulties in sustaining their QC efforts (Hill 1991). Among other challenges, the restriction of QC activities to a narrow range of issues within the control of the work unit, the tendency to run out of things to do, the lack of training or incompetence of employees, and the managerial attitude and culture leading to a lack of co-operation, notably among supervisors and middle managers (Collard and Dale 1989) come to the fore. 


\section{RESEARCH METHOD}

Much of the literature concerned with the role of small-group activities and QCs in work improvement date back to the 1980s, when those practices were first adopted from Japan and gained popularity in the West. However, CI cells go beyond the usual scope of QCs by facilitating daily or weekly work planning/ control and by exposing other team related information such as Health and Safety figures or team member availability to the team members. What is more, empirical research on the use and implications of the concept in construction supply chains is scarce. Also, despite the increasing adoption of CI cells in the highways supply chain in the UK, no specific account on the realisation of the current CI cell practices was identified. Therefore, three research questions were posed to explore the condition of CI cells in the highways supply chain:

1) How is the CI cell mechanism executed?

2) What are the benefits of CI cells?

3) What are the current challenges for CI cells?

12 internal CI cells of the highways supply chain's main client were studied using interviews, participant observation in CI cell meetings, CI cell board observations and discussions with the team members. The details of the data collection with each team can be seen in Table 1. As explained in the subsequent section, two main types of CI cells were found in effect; Type I cells Type II cells. There are also real cells in which the team members are co-located and virtual cells, which are executed over the internet, intranet or telephone. The cells were studied in two different headquarters of the main client in Northern England; A and B.

Table 1: Data Collection Methods with Each Team

\begin{tabular}{|c|c|c|c|c|c|c|c|}
\hline \multicolumn{4}{|c|}{ General Information } & \multicolumn{4}{|c|}{ Data Collection Methods } \\
\hline $\begin{array}{c}\text { Cl Cell } \\
\text { No }\end{array}$ & Location & $\begin{array}{l}\text { Cl Cell } \\
\text { Type }\end{array}$ & $\begin{array}{l}\text { Virtual } \\
\text { or Real } \\
\text { Cl Cell }\end{array}$ & Interviews & $\begin{array}{c}\text { Cl Cell } \\
\text { Board } \\
\text { Observation }\end{array}$ & $\begin{array}{c}\text { Cl Cell } \\
\text { Meeting } \\
\text { Participant } \\
\text { Observation }\end{array}$ & $\begin{array}{c}\text { Discussions } \\
\text { with Team } \\
\text { Members }\end{array}$ \\
\hline 1 & A & Type II & Virtual & $\begin{array}{l}2 \text { team } \\
\text { members }\end{array}$ & Done & No & Done \\
\hline 2 & A & Type I & Real & $\begin{array}{l}1 \text { team } \\
\text { member }\end{array}$ & Done & No & Done \\
\hline 3 & A & Type II & Real & $\begin{array}{l}2 \text { team } \\
\text { members }\end{array}$ & Done & Done & Done \\
\hline 4 & A & Type I & Real & $\begin{array}{l}1 \text { team } \\
\text { member }\end{array}$ & Done & Done & Done \\
\hline 5 & $A$ & Type I & Real & $\begin{array}{l}1 \text { team } \\
\text { member }\end{array}$ & Done & Done & Done \\
\hline 6 & A & Type I & Real & No & Done & $\begin{array}{c}\mathrm{N} / \mathrm{A} \text { - Team } \\
\text { stopped their } \\
\mathrm{Cl} \text { cell } \\
\text { meetings }\end{array}$ & Done \\
\hline
\end{tabular}




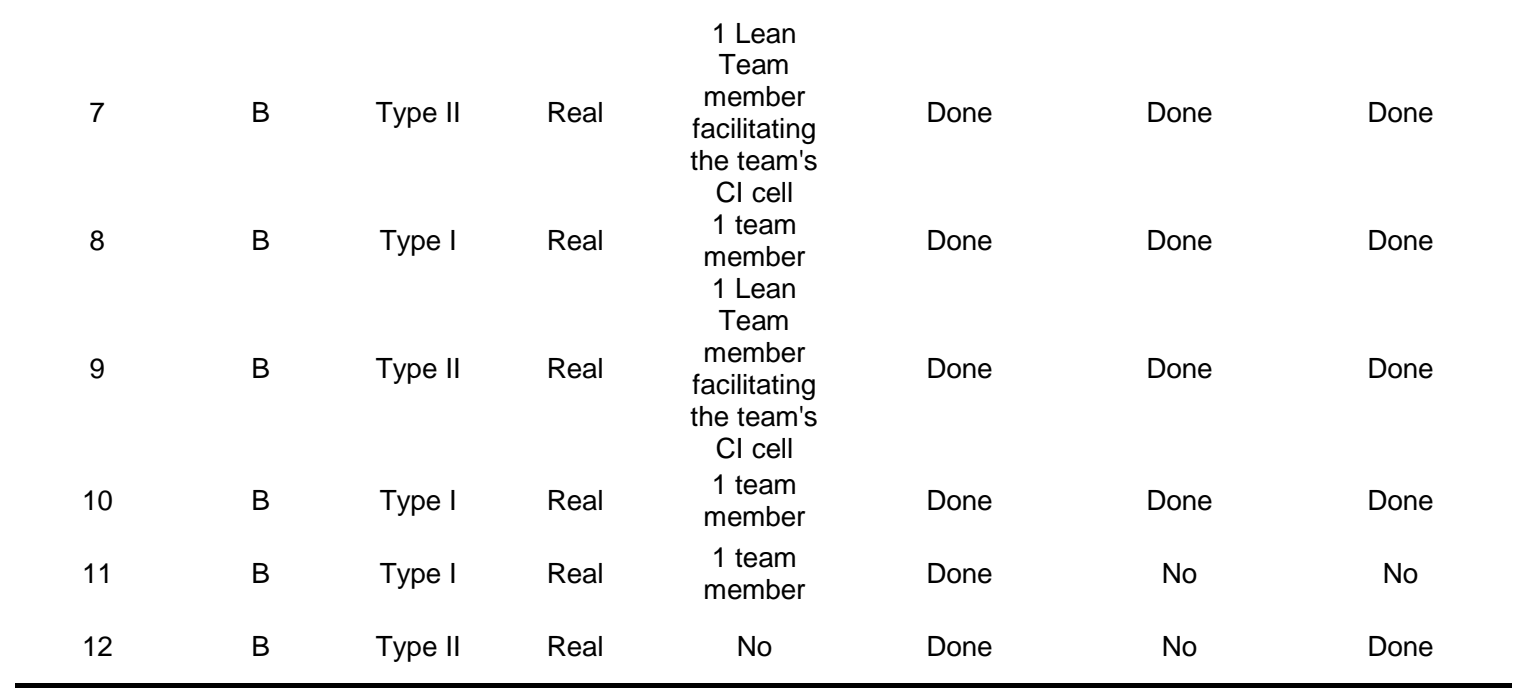

\section{FINDINGS}

\section{EXECUTION OF CONTINUOUS IMPROVEMENT CELLS}

A CI cell is made up of two things in practice; (i) a regular (daily, weekly or bi-weekly) meeting mechanism led by the team leader, and (ii) a physical (real) board for co-located teams or a virtual medium (e.g. a spreadsheet on the intranet)for dispersed teams with different sections, typically containing the team KPI, task control and coordination, team member availability, health and safety and continuous improvement data, that enables and acts as the visual data record of that meeting mechanism.

Of the two types of CI cells, the Type I cells are more focused on work coordination and planning with minimal or ad-hoc work improvement. There are three sections generally covered in Type I cell meetings and cell boards; (i) team member availability often in the form a team member availability matrix for the week commencing, (ii) a work planning and control section in which each team member can negotiate with other team members and visually declare his/her responsibility for the completion of a task and can provide updates on the task's completion by using post-it notes, and (iii) a notes section displaying key events or success stories. Some Type I cell boards also display team KPIs.

Alongside work coordination, the systematic execution of continuous improvement efforts in the Type II cells is more conspicuous than the Type I cells. A Type II cell boards contains generally three main sections; (i) a team performance section, in which various team KPIs are collectively reviewed and evaluated by the team members, (ii) a 3Cs section (Concerns, Causes and Countermeasures), in which current and anticipated work issues are captured and discussed with their root reasons and preventive actions. Countermeasures defined as best practices are communicated and disseminated for future use along with success stories, and (iii) a section showing various Human Resources related figures (i.e. team members' availability, absence statistics, training information etc.). The structure of the Type II cell boards is more standardised. Also, the Type II cells 
were often initiated and are facilitated by one of the organisation's process improvement staff member. The two types of cells and the $3 \mathrm{C}$ can be seen in Figures 2, 3 and 4 respectively.

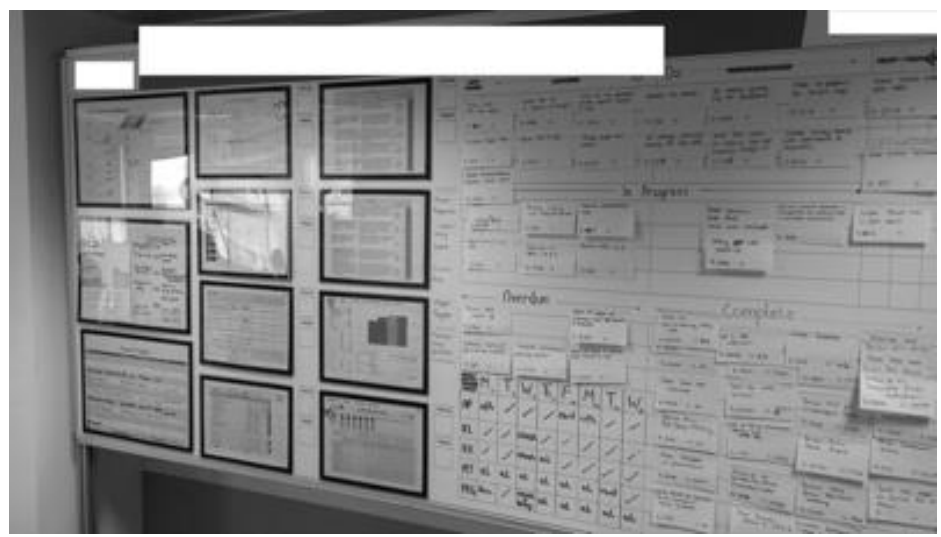

Figure 2: A Type I cell board containing information on some team KPIs (left), a team member availability matrix (bottom-right) and a task tracking section (top-right).

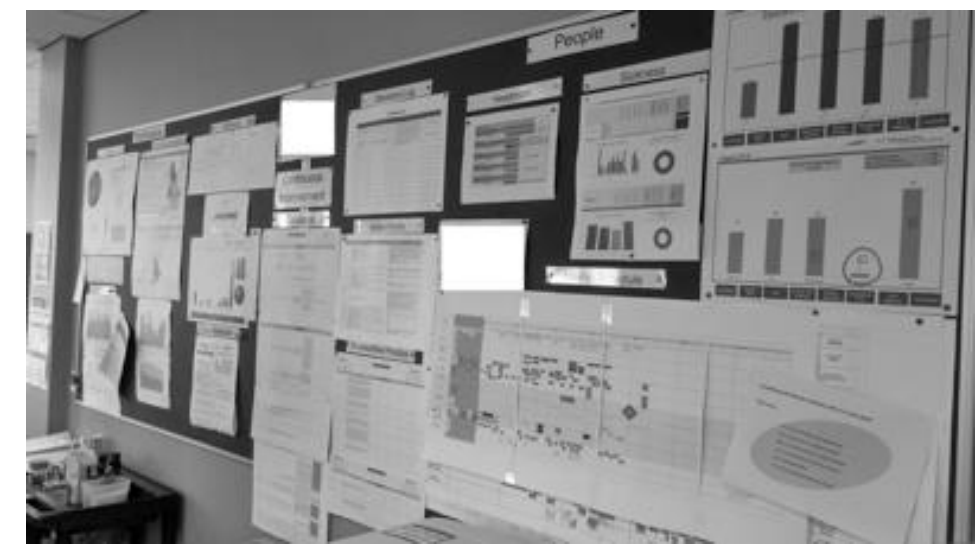

Figure 3: A Type II cell board comprised of three sections; team KPIs (left), a continuous improvement section with the 3Cs (centre) and the people (Human Resources) section (right) 


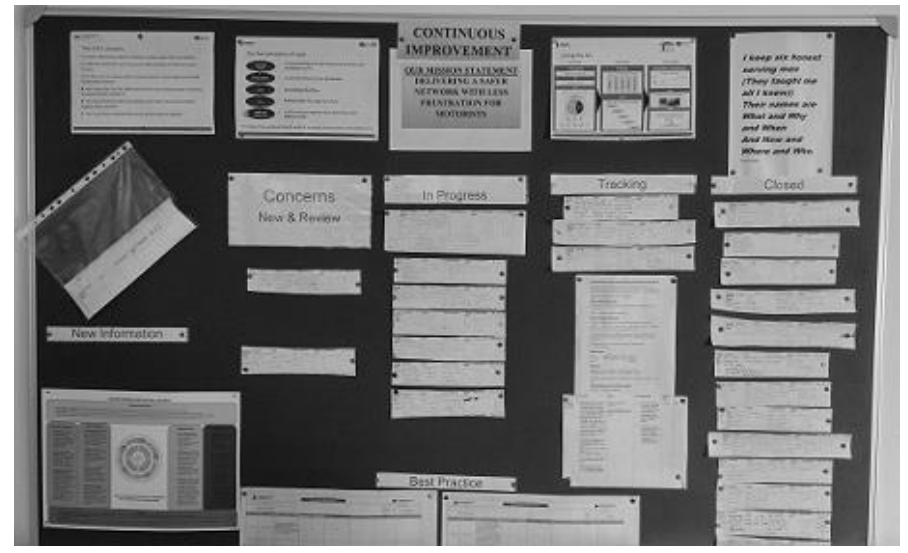

Figure 4: The 3C section of a CI cell board. The continuous improvement function of CI cells has generally been executed and recorded over the $3 \mathrm{C}$ template in the highways supply chain.

\section{BENEFITS OF CONTINUOUS IMPROVEMENT CELLS}

The following CI cell benefits were identified, in no particular order of importance, from the interviews and participant observations at the client organisation. The findings were compiled from the recurring themes from the interviews, followed and verified by the CI cell meeting observations and the informal discussions with the team members. A CI cell:

- enables having structured and succinct team meeting,

- supports coordination of team work,

- increases team engagement and morale,

- discloses related information to employees,

- increases transparency,

- helps with team building,

- facilitates task ownership,

- prompts team members to make more reliable promises (peer pressure)

- helps teams allocate and level their resources (work balancing/ prioritising)

- serves as a training mechanism for junior and new team members,

- supports task delegation, empowerment and employee autonomy,

- simplifies progress reporting and creating meeting minutes,

- helps save team resources.

\section{CHALLENGES FOR CONTINUOUS IMPROVEMENT CELLS}

The main challenges in the execution of the CI cells as identified in the same way as the CI cell benefits are:

- ad-hoc and unstandardized data recording, 
- not understanding what to measure and how to measure with respect to CI cell benefits,

- hardships faced in identifying root causes of problems,

- ad-hoc problem solving,

- insufficient standardisation among the teams in their CI cell executions (i.e. the frequency of meetings, the content and design of the CI cell boards, the governance of the CI meetings, some teams' ignoring the continuous improvement function),

- providing the team with only basic training as to the CI cell execution and systematic problem solving techniques,

- root problem causes not being systematically recorded, classified and visualised,

- the lack of senior management engagement,

- the lack of systematic incentivisation practices for the CI cells,

- the limited authority of the teams to make work improvements as they are mostly restricted with their work domains.

\section{DISCUSSION}

Both the identified benefits and challenges from the main client match with the existing literature to a great extent. Four additional CI cell benefits stand out; (i) the CI cells act as a training mechanism for junior team members and newcomers, (ii) the cells increase the transparency in team information, (iii) the cells' role in executing focused team meetings and (iv) in simplifying the reporting process. The challenges are mostly related to the lack of incentivisation, proper training, standardisation and engagement of the senior management. It should be noted, however, that further empirical research is necessary to prioritise the identified benefits and challenges.

The captured transparency increasing benefit of CI cells further justifies its role in increasing process transparency and supporting Visual Management (Figure 1). However, some issues in the continuous improvement (kaizen) function of the cells like root cause problems not being systematically recorded, ad-hoc problem solving or some teams' ignoring the CI cell's continuous improvement function were identified in practice. Also, due to the fact that senior management do not have their CI cells at the moment, there are issues regarding the two-way flow of information over the CI cells from the strategic level to operational level and vice versa for the execution of hoshinkanri. The studied teams' limited capability in making work improvement beyond their control domain can be attributed to this interruption in the information flow between the strategic and the operational level.

As for the suggestions, the client organisation should review its Lean training curriculum to include more of the basic root cause analysis and problem solving methods. A comprehensive audit of the existing CI cells across the organisation to increase the standardisation will be useful. Additionally, the senior management can be prompted to form their own CI cells, which should be linked to their subordinates' CI cells to form a 
complete information cycle in the organisation over the CI cells. Not only will this help the senior management connect with their subordinates, it will also support the work teams to solve some persistent problems that go beyond their team's authority, control and work domain. Work improvement cannot be ordered but should rather be supported. Also, the teams can be guided on how to record their CI cell data and CI cell benefits systematically.

The CI cells' potential in supporting the continuous improvement objective of and daily huddle meetings in the Last Planner System, which are some of the least executed parts in the Last Planner practices in the UK (Daniel et al. 2017), should also be highlighted. Issues emerging from the Last Planner's weekly meeting can be transferred to and studied for continuous improvement within a CI cell mechanism. Also, site teams can have their daily huddle meetings around their CI cell boards to review their daily work plan and work improvement objectives.

\section{CONCLUSIONS}

Continuous improvement (kaizen) is a key element of Lean Construction. One of the means to realise continuous improvement in practice is using the CI cell technique. CI cells also can be positioned within other important lean concepts like Visual Management and hoshinkanri. However, the CI cell research in construction has remained scarce.

This paper presented a summary and preliminary findings of a research project exploring the execution of the CI cell technique in the highways supply chain in the UK. The identified benefits can be tested and prioritised in the future with data from different organisations and quantitative methods (i.e. design of experiments and action research). The identified challenges are also deemed important in improving the current CI cell adoption. Deploying CI cells in construction supply chains and linking them with other Lean Construction techniques like the Last Planner or Visual Management systems can be also an option in the future for case studies, design science or action research based investigations.

\section{ACKNOWLEDGMENTS}

The authors would like to thank Highways England and its suppliers for their support.

\section{REFERENCES}

Akao, Y. (1991). HoshinKanri: Policy Deployment for Successful TQM. Productivity Press, Cambridge, USA.

Barad, M. (2018). Strategies and Techniques for Quality and Flexibility. Springer, Cham, Switzerland.

Bell, S. (2005). Lean Enterprise Systems: Using IT for Continuous Improvement. John Wiley \& Sons, Hoboken, US.

Bititci, U., Cocca, P., and Ates, A. (2016). "Impact of Visual Performance Management Systems on the Performance Management Practices of Organisations." International Journal of Production Research, 54(6), 1571-1593. 
Bradley, K., and Hill, S. (1983). “'After Japan': The Quality Circle Transplant and Productive Efficiency." British Journal of Industrial Relations, 21(3), 291-311.

Brown, A. (2013). "Managing Challenges in Sustaining Business Excellence." International Journal of Quality \& Reliability Management, 30(4), 461475.

Brunet, P. A., and New, S. (2003). "Kaizen in Japan: An Empirical Study." International Journal of Operations \& Production Management, 23(12), 1426-1446.

Collard, R., and Dale, B. (1989). Quality Circles. Personnel Management in Britain, Blackwell, Oxford, UK.

da Silveira, G. W., Pinheiro de Lima, E., Gouvea da Costa, S. E., and Deschamps, F. (2017). "Guidelines for HoshinKanri Implementation: Development and Discussion." Production Planning \& Control, 28(10), 843-859.

Daniel, E. I., Pasquire, C., Dickens, G., and Ballard, H. G. (2017). "The Relationship between The Last Planner ${ }^{\circledR}$ System and Collaborative Planning Practice in UK Construction." Engineering, Construction and Architectural Management, 24(3), 407425.

Galsworth, G. D. (2005). Visual Workplace: Visual Thinking, Visual-Lean Enterprise Press, Portland, USA.

Hill, S. (1991). "Why Quality Circles Failed but Total Quality Management Might Succeed." British Journal of Industrial Relations, 29(4), 541-568.

Prado, J. C. (2001). "Beyond Quality Circles and Improvement Teams." Total Quality Management, 12(6), 789-798.

Dale, B. G., Elkjaer, M. B. F., Van der Wiele, A., and Williams, A. R. T. (2001). "Fad, Fashion and Fit: An Examination of Quality Circles, Business Process ReEngineering and Statistical Process Control." International Journal of Production Economics, 73(2), 137-152.

Imai, M. (2012). Gemba Kaizen: A Common Sense Approach to Continuous Improvement Strategy, 2nd ed., McGraw-Hill Professional, New York, USA.

Love, P.E.D., and Li, H. (2000). "Overcoming the Problems Associated with Quality Certification." Construction Management \& Economics, 18(2), 139-149.

Maarof, M. G., and Mahmud, F. (2016). "A Review of Contributing Factors and Challenges in Implementing Kaizen in Small and Medium Enterprises." Procedia Economics and Finance, 35, 522-531.

Miron, L., Talebi, S., Koskela, L., and Tezel, A. (2016). "Evaluation of Continuous Improvement Programmes." In Proc. 24th Ann. Conf. of the Int'l. Group for Lean Construction, Boston, MA, USA.

Osayawe, E. B., and McAndrew, E. B. (2005). "Innovation, Diffusion and Adoption of Total Quality Management (TQM)." Management Decision, 43(6), 925-940.

Pereira, G. M., andOsburn, H. G. (2007). "Effects of Participation in Decision Making on Performance and Employee Attitudes: A Quality Circles Meta-Analysis.” Journal of Business and Psychology, 22(2), 145-153

Suzaki, K. (1993). The New Shop Floor Management: Empowering People for Continuous Improvement. The Free Press, New York. 
Tezel, A., Koskela, L., and Tzortzopoulos, P. (2016). "Visual Management in Production Management: A Literature Synthesis." Journal of Manufacturing Technology Management, 27(6), 766-799.

Wilkinson, A., Godfrey, G., and Marchington, M. (1997). "Bouquets, Brickbats and Blinkers: Total Quality Management and Employee Involvement in Practice." Organization Studies, 18(5), 799-819.

Witcher, B. J., and Butterworth, R. (2001). "HoshinKanri: Policy Management in Japanese - Owned UK Subsidiaries." Journal of Management Studies, 38(5), 651674. 